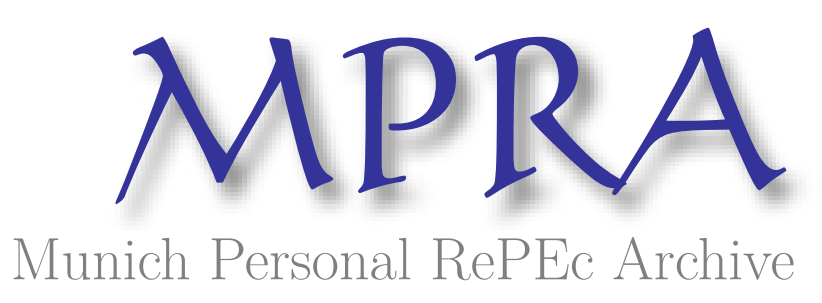

\title{
The Widening Black-White Wage Gap among Women
}

Houseworth, Christina and Fisher, Jonathan

Hobart and William Smith Colleges

2017

Online at https://mpra.ub.uni-muenchen.de/81884/

MPRA Paper No. 81884, posted 03 Nov 2017 09:13 UTC 


\title{
The Widening Black-White Wage Gap among Women
}

\author{
Jonathan D. Fisher ${ }^{1}$ - Christina A. Houseworth ${ }^{2}$
}

Abstract. We utilize over 30 years of the Current Population Survey to examine labor force participation and wage patterns among five cohorts of white and black women. By estimating wages using four selection correction techniques in determining the wage gap for women who are not in the labor force, we provide evidence of the changing role of selection among women over time. We find an increasing observed wage gap between white and black women for younger cohorts; however, the decline in selection for both black and white women does not explain the rising wage gap.

\section{Introduction}

This paper examines the black and white wage gap and labor force participation gap by cohort among women born since 1928. Differences in the wage gap by cohort are drastic. When in their early 30s, women in the Baby Boom 1 cohort have a wage gap of roughly 5 per cent in favor of white women, where the corresponding gap is over 15 per cent in Generation $\mathrm{X}$, a generation comprised, in large part, of the daughters of Baby Boom 1. A cohort framework focuses on the cultural and socio-economic differences across generations that shape the labor force decisions and wages of women. Many factors affect the cohorts of women differently, including the rise of dual earner households in the 1970s, stagnation in male wages since the late 1970s, the delay in marriage and childbearing, welfare reform of the 1990s, and the rise of birth control options for women.

The racial wage gap literature has focused mainly on men, as they have been the majority of wage earners in the 20th century and, on average, the largest contributors to household income. Disparities among men, therefore, helped to explain disparities among households as a whole. However, currently non-institutionalized black women participate in the labor force at the same rate as non-institutionalized black men, and there are more black women in the labor force than black men in part because of the high institutionalization rate for black men. ${ }^{1}$ With these changes, it becomes vitally important to understand the racial wage gap among women.

This paper contributes to the literature by providing a description of changes over time by cohort for black and white women with regards to labor force participation and wages.

We are thankful to the participants at the 2014 Southern Economic Association Meetings for helpful feedback, as well as Barry Hirsch and Tara Watson. We are especially grateful to Kaiya DiPippo for her work as a research assistant on this project. We also thank the editor and the anonymous referee for their thoughtful feedback.

${ }^{1}$ Center on Poverty and Inequality, Stanford University, 450 Serra Mall, Building 370, Stanford, CA, 94305, USA.

E-mail: jonathan.fisher@stanford.edu

${ }^{2}$ Economics Department, Hobart \& William Smith Colleges, Geneva, NY, USA. 
Documenting these important trends across cohorts is vital given the relatively scant amount of research in this area and the changing role of women in the labor market. These changes are multifaceted and differ by race. We provide a detailed discussion of these changes and the supporting literature that has analysed the effect on labor supply. Although we do not provide detailed causal evidence on why the wage gap increases, we do analyse selection into employment utilizing four selection correction techniques and therefore provide important evidence of the changing role of selection among women over time. We believe this important first step is a valuable jumping off point for researchers interested in analysing any of the contributing factors to the change in labor force among women on wages.

The limited research in this area has only focused on one or two generations, focused on women aged 26-31, and used only one method to address for selection into employment. We go further and put the two generations in a bigger context by focusing on women aged 25-55, adding older cohorts, adding younger cohorts, and testing the sensitivity of the results to different selection correction methods. Although each selection correction method we utilize has issues, the fact that each selection method produces similar results provides a unique robustness check.

We utilize the Annual Social and Economic Supplement (ASEC) and the Merged Outgoing Rotation Groups (MORG) from the Current Population Survey (CPS) to examine labor force participation patterns among white and black women aged 25-55 for five cohorts: Post-War, born between 1928 and 1945; Baby Boom 1 cohort, born between 1946 and 1954; Baby Boom 2 cohort, born between 1955 and 1965; Generation X, born between 1966-76; and partial Generation Y, born between 1977-88.

We find that both black and white women in younger cohorts are more likely to work, and that previous (opposing) selection stories for black and white women are no longer as convincing as they were for older cohorts. For instance, Neal (2004) finds that black women are likely to be positively selected into the labor market, where there is no evidence of positive selection for white women. However, we find that white, highly educated women in younger cohorts are much less likely to leave the labor force during childbearing years than older cohorts, and consequently, median wages for the younger cohorts do not fall as they do for the older cohort. The declining exodus of white women from the labor market during childbearing years indicates that selection into the labor market by white women may be positive, at least in this age range. We also find a larger percentage of single black mothers in the labor force, indicating that positive selection into the labor force for black women is declining.

Additionally, there are differences between labor force participation across cohorts between black and white women by education level. Black women on the low end and white women on the high end of the education distribution in younger cohorts have increased their labor force participation. Changes in the timing of childbirth and welfare reform may be responsible for these patterns. Each of these changes should increase the observed wage gap between white and black women. We find an increasing observed wage gap between white and black women for younger cohorts; however, the decline in selection for both black and white women does not explain the rising wage gap given that the wage gap remains significantly larger for younger cohorts after controlling for selection into the labor market.

The paper proceeds as follows. Section 2 provides a background of the social, economic, and policy changes related to female labor supply and wages. Section 3 provides a brief overview of the data. We examine differences in labor force participation by cohort in 
Section 4. Section 5 discusses regression results by cohort with and without controls for selection using four methods. A discussion of the rising wage gap among black and white women, the related labor force participation patterns, and the role of selection are discussed in Section 6. Section 7 concludes.

\section{Background}

Pivotal work by Neal (2004) recognizes that selection into employment is not only important for men. He finds that the female racial wage gap, once controlling for selection, is at least 60 per cent larger between young black and white women from the Baby Boom 2 generation. Among highly educated women, Fisher and Houseworth (2012) find that there is no wage gap between black and white women, even when controlling for selection into employment. Using the same cohort of women as Neal (2004), McHenry and McInerney (2014) find a wage premium for black women that disappears when controlling for differential costs-of-living as black women are more likely to live in higher cost and therefore higher wage areas.

Albrecht et al. (2015), use the 1979 National Longitudinal Survey of Youth (NLSY) and the 1997 NLSY to examine the median distribution of wages for both white and black women in 1990 and 2011, comparing the young women of Baby Boom 2 to Generation Y. They find an increase in the median wage gap between white and black women between 1990 and 2011. They argue that a proportionally higher increase in the education of white women relative to black women partially explains their results. We expand on Albrecht et al. (2015) by studying five cohorts of women using the CPS. We determine whether the findings from Albrecht et al. are unique to the particular generation studied, or a larger trend toward a widening wage gap. We also expand beyond Albrecht et al.'s focus on women in their late 20 s and early 30 s by including all prime working age women. The racial wage gap is not constant across ages and thus it is important to focus on a wide age range.

The theoretical underpinnings for our analysis are straightforward. The decision to work depends on market wages and reservation wages. Goldin et al. (2006) focus on the differential trends that led women to now complete college at a higher rate than men, such as changing expectations on future labor force attachment, social norms, and increased access to contraceptives. Those same factors affect labor force participation of women. The remainder of this section discusses these and other factors that differentially impact the market wages and reservation wages of white and black women over the 38 years of data utilized herein.

The marriage markets for black and white women differ and have disproportionately worsened for black women relative to white women. The number of black men who have ever been incarcerated has steadily increased since the late 1970s: 704,000 black men were incarcerated in 1979, 1,181,000 in 1991 and 1,936,000 in 2001 (Bonczar, 2003). Additionally, black men's wages continue to be significantly lower than white men's wages. Hirsch and Winters (2014) use data from the decennial census and American Community Surveys to compare earnings for all white, Hispanic, and black men, as opposed to most previous research that restricted to the non-institutionalized male population. They find the widening annual earnings gap between white and black men is partially due to the increasing rate of joblessness among black men over time. They find the largest difference in earnings between white and black men since 1950. Hirsch and Winters (2014) attribute the rise in 
the wage gap to increasing joblessness among black men in significant part because of increased institutionalization of black men. Black women, however, are now more likely to be in the labor force than older cohorts. The link between the increasing black male incarceration rate and female labor force participation is partially explained through the marriage market.

The deterioration of the marriage market for black women has resulted in marriage rates steadily declining. Besharov and West (2002) find the percentage of black women who have never been married increased from 21 per cent to 41 per cent between 1950 and 1998 whereas white women only experienced a small increase, from 20 to 22 per cent. A worsening marriage market is predicted to increase the labor force participation for black women. Given the decrease in marriageable black men (in terms of employment status and the propensity to be incarcerated) and the increase in positive assortative matching on education over time in the U.S. (Greenwood et al., 2014), female labor force participation among black women is expected to increase at a greater rate at the bottom of the wage distribution. Thus, the female racial wage gap is predicted to increase as a result of the declining marriage market for black women as more low wage black women enter the labor force due to a decline in their reservation wage.

In addition to differences in the marriage market and the propensity to be married, changes in spousal income over time also affect the labor force participation of married women. Mishel et al. (2012) show that wages for men in roughly the middle of the wage distribution have either declined between 1979-2011 or increased only minimally. However, for the same time period and section of the distribution, women's wages have increased between 13 and 36 per cent. More women are predicted to enter the labor force as their husband's earnings decline. Given that white women are more likely to be married and married to an employed white male, stagnating male wages will have a relatively larger effect on the labor force participation of white women.

Another factor lowering the reservation wage of black women disproportionately is the movement in the social safety net in the U.S. away from cash transfers toward tax credits. The Personal Responsibility and Work Opportunity Reconciliation Act (PRWORA) of 1996 implemented major revisions to welfare policy in the U.S. Ongoing work requirements were established and child-care assistance programs were replaced with a single Child Care and Development Block Grant. Across the states there were several common changes. Namely, reductions in benefit levels, lower benefit reduction rates, an increase in welfare to work programs, sanctions, time limits (only eight states have not imposed any time limits that end benefits), and work support subsidies. Around the same time, the Earned Income Tax Credit (EITC) expanded and made work more beneficial.

Each of these tax law and social safety net changes are predicted to increase labor force participation among low-income households. Blank (2002) not only provides a detailed description of all of these changes, but also provides evidence that these changes are at least partially responsible for a reduction in welfare caseloads, and an increase in labor force participation.

Finally, social attitudes, cultural changes, and the perception of roles that men and women play influence the proportion of women who participate in the labor force and continue to change significantly over time. From the 1920 s to the 1960 s, married households were dominated with a system in which the husband worked and the wife stayed at home with children. By 2000, more than fifty per cent of married households were comprised of two spouses in the labor force (Ruggles, 2014). Social attitudes may also be an important determinant of female labor force participation. In 1987, 30 per cent of Americans believed 
women should return to their traditional roles in society, while in 2009 only 19 per cent of Americans agree with this statement (Pew Research Social \& Demographic Trends, 2009).

Additionally, the rise in methods and quality of existing methods of birth control over time has both decreased the number of childbirths and delayed childbirth. As women have fewer children at later ages, their labor force participation increases (Bailey, 2006). Prior to the Affordable Care Act of 2010, several forms of birth control were not easily accessible to those without relatively high incomes or health insurance. As young black women are more likely to be in low-income households without health insurance, changes in labor force participation by cohort may be more noticeable for black women.

These social and labor market changes will not only affect the current generation at the time of the change, but also their children's participation. The percentage of women who grew up in households with a working mother increased substantially. Between 1970 and 1980 the labor force participation rate for females with children under the age of 18 rose from 39.7 to 54.1 (US Census Bureau, Table 599). More than half of all mothers with toddlers were in the labor market in 1987, compared to less than one fourth in 1967 (Shank, 1988). If black mothers are historically more likely to work than white mothers, then the differences between cohorts should be more pronounced for white women than black women.

The increase in female market wages, changing social and cultural attitudes towards women working, and the many factors discussed above influencing reservation wages all point toward higher labor force participation among women. Although both black and white women have experienced an increase in labor force participation for younger cohorts, the change in who is more likely to work differs between black and white women. As more potential high wage white women and potential low-earning black women enter the labor market, the wage gap between white and black women should increase for younger cohorts. The relationship between labor force participation patterns across cohorts and the racial wage gap is the focus of this paper, and discussed in detail in Section 6.

\section{Data}

We utilize the Merged Outgoing Rotation Groups (MORG) from the Current Population Survey (CPS) from 1979 to 2014 to examine patterns in labor force participation and wages by cohort and race. Although the MORG provides limited demographic variables, the sample sizes are much larger than the CPS Annual Social and Economic Supplement (ASEC). The MORG includes marital status, child status, education level, self-employment status, full-time worker status, state of residence, and metropolitan status. The ASEC provides additional information on other household income not available in the MORG. For the majority of the analysis we will use the MORG, but when analysing the wage gap with and without selection controls we will also use the ASEC, which provides detailed information on additional variables useful in correcting for selection into employment among women as described below. The MORG provides information on hourly wages for those paid hourly as well as usual weekly earnings, and usual hours worked for salaried workers. In the MORG, we use reported hourly wage for those paid hourly. For salaried workers, we divide usual weekly earnings by usual hours worked per week to estimate the hourly wage. We create an hourly wage in the ASEC by dividing annual earnings by weeks worked and usual hours worked per week. 
We restrict the sample to non-self employed women aged $25-55 .^{2}$ Individuals with topcoded earnings were assigned an hourly wage equal to that value divided by weeks times hours worked per week. ${ }^{3}$ We also restrict to those who identify themselves as non-Hispanic white alone or non-Hispanic black alone. All dollar values are adjusted to 2012 using the Consumer Price Index Research Series (CPI-U-RS). Participation and wage gaps are measured as the quotient of white participation (or median wage) to black participation minus one. Therefore, a gap of 0.20 corresponds to a 20 per cent higher wage among white women, and a gap of -0.20 corresponds to a 20 per cent lower wage for white women.

We define the cohorts consistently across the MORG and ASEC. To reiterate, the five cohorts we analyse are: Post-War, born between 1928 and 1945; Baby Boom 1, born between 1946 and 1954; Baby Boom 2, born between 1955 and 1965; Generation X, born between 1966-76; and partial Generation Y, born between 1977-88.

\section{Wages and labor force participation}

Figure 1a shows median wages by cohort, race, and age, and Figure $1 \mathrm{~b}$ displays the median wage gap by cohort and age using the MORG. ${ }^{4}$ The median wage is higher for white women across all cohorts and ages. Another distinct pattern in Figure 1a is that median wages for white women in our three younger cohorts are at least as high or higher than median wages for white women in the older cohorts, whereas the opposite occurs for black women. These differences translate into larger wage gaps for the three younger cohorts (Figure 1b). Our first major finding is that the observed wage gap is higher for younger cohorts. Before age 35, the wage gap for Baby Boom 1 is from 5 to 10 per cent, whereas the wage gap for our three younger cohorts is around 15 per cent.

The wage gap is likely to be related to changes in labor force participation; hence we next examine labor force participation by race, cohort, and age. Figure $2 \mathrm{a}, \mathrm{b}$ confirm the general patterns observed elsewhere (Blau and Kahn, 2007; Juhn and Potter, 2006). Labor force participation is higher for more recent cohorts. The increase in labor force participation is larger for white women, as evidenced in Figure 2a,b. The change across generations is starkest after the two earliest cohorts, the Post-War cohort and the Baby Boom 1 cohort. Between 26 and 33 year olds, the labor force participation rates for Generation $\mathrm{X}$ and $\mathrm{Y}$ are between 7 to 11 percentage points higher than the Baby Boom 1 cohort for black and white women.

Section 2 above discusses several reasons why the labor force participation gap is likely to change over cohorts and why it is likely to be different by race. For our younger cohorts, we expect more married white women with children to be in the labor force, and we expect more single black women with children to be in the labor force. Figure 3a,b confirm these patterns. ${ }^{5}$ Labor force participation among white women with children is 10 percentage points higher for our three younger cohorts from ages 25-30, compared to Baby Boom 1, whereas there is no change across cohorts for married black women with children (Figure 3a). Klerman and Leibowitz (1995) attribute this change to a decrease in number of children and changes in earning opportunities. Additionally, white women in younger cohorts with a college diploma are more likely to be in the labor force than their older cohort counterparts (Figure 4b). The same pattern for college graduates is not present for black women. College educated white women and white women with children are now more likely to work. 
Figure 1. (a) Median wages: white and black women by cohort and age. (b) Median wage gap between white and black women by cohort and age

(a)

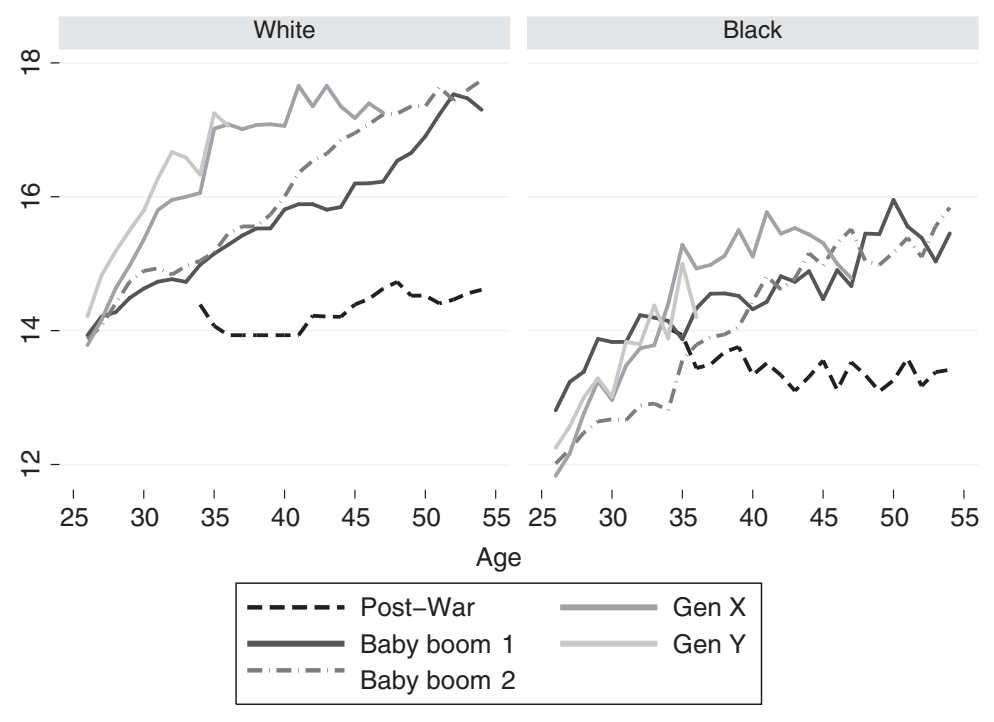

(b)

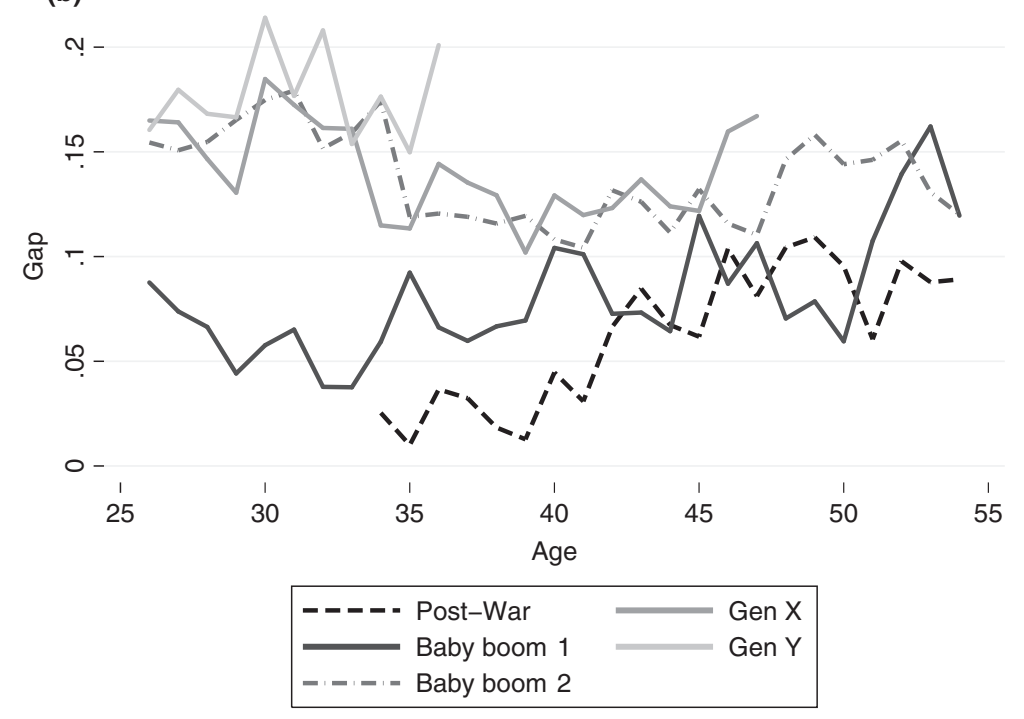

Source: Current population survey merged outgoing rotation groups 1979-2014.

Single black women with children and black women with low levels of education are the most likely to be affected by welfare reform. Figures $3 \mathrm{~b}$ and $4 \mathrm{a}$ confirm these predictions. In their 20s and early 30s, Generation X and Generation Y exhibit higher labor force participation rates than the two Baby Boom generations, suggesting welfare reform, among other factors, may have a role in increasing labor force participation during childrearing 
Figure 2. (a) Labor force participation rates: white and black women by cohort and age. (b) Labor force participation gap between white and black women by cohort and age

(a)

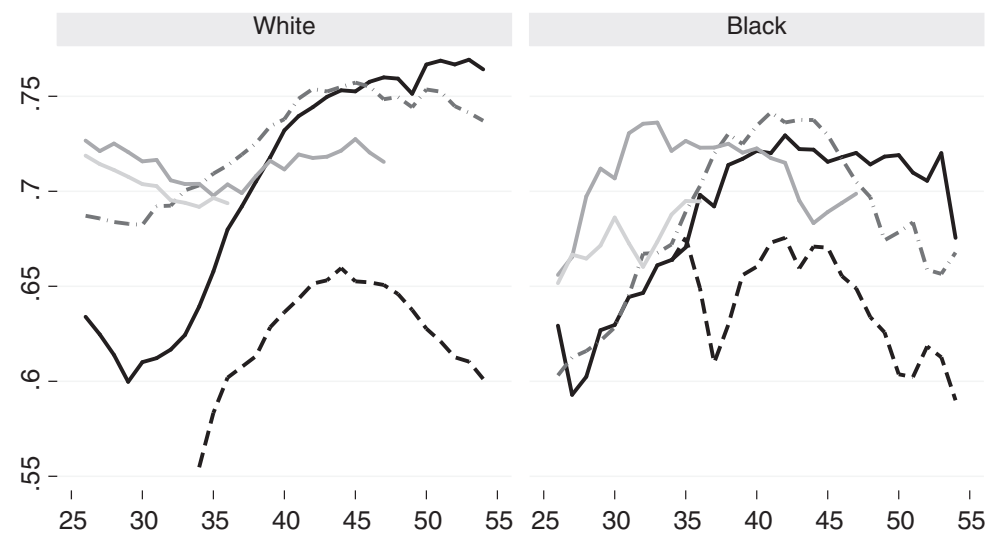

Age

(b)

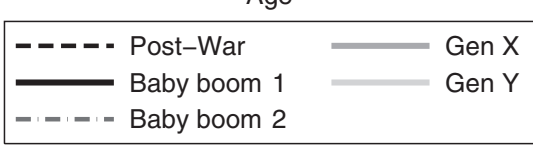

กุ-

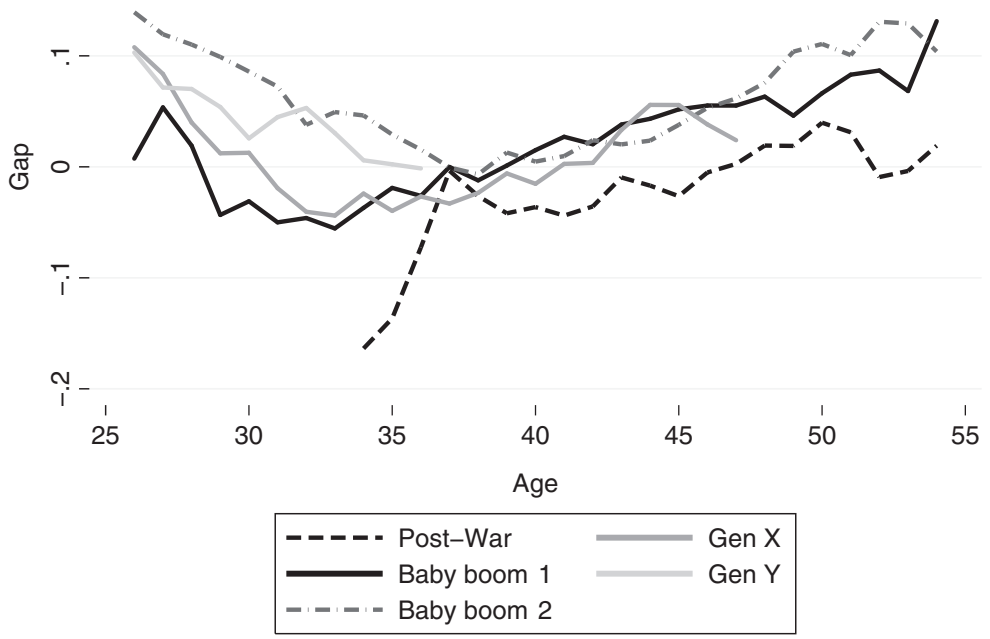

Source: Current population survey merged outgoing rotation groups 1979-2014.

years as these were the first generations affected by PWORA's work requirements (Figure 2a). Among single women with children, black women in their late 20 s in the two younger cohorts most affected by welfare reform are more likely to be in the labor force than Baby Boom 1 and Baby Boom 2 (Figure 3b). Further, there are a higher percentage of black women under the age of 35 with a high school diploma or less in the labor force 
Figure 3. (a) Labor force participation by race for married women with children. (b) Labor force participation by race for single women with children

(a)

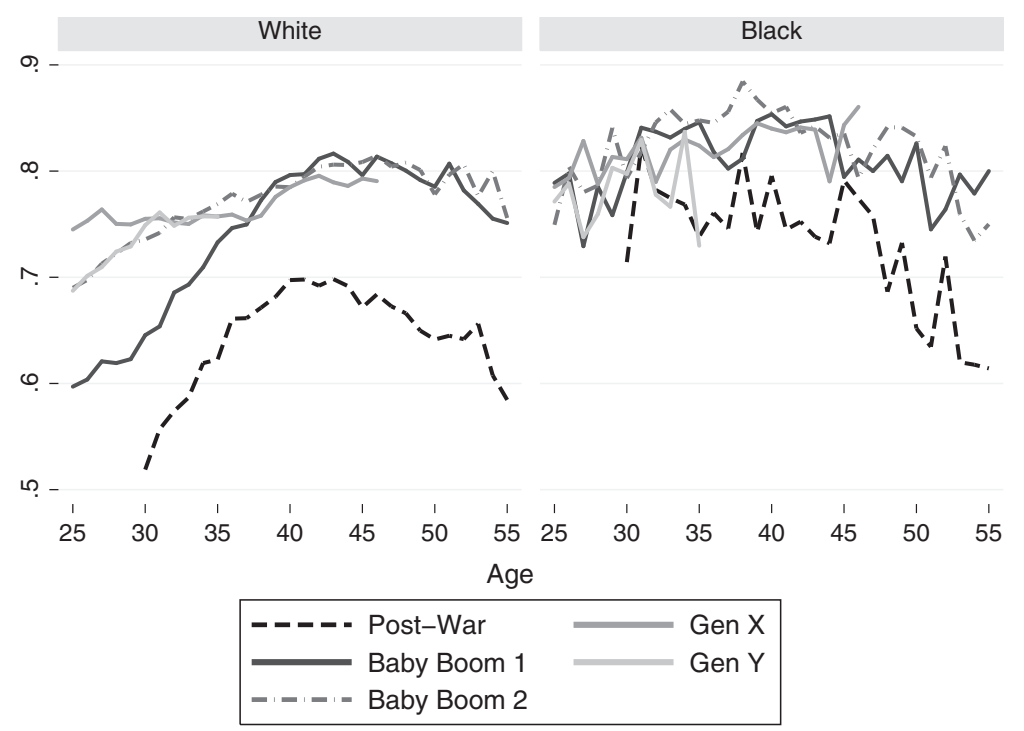

(b)
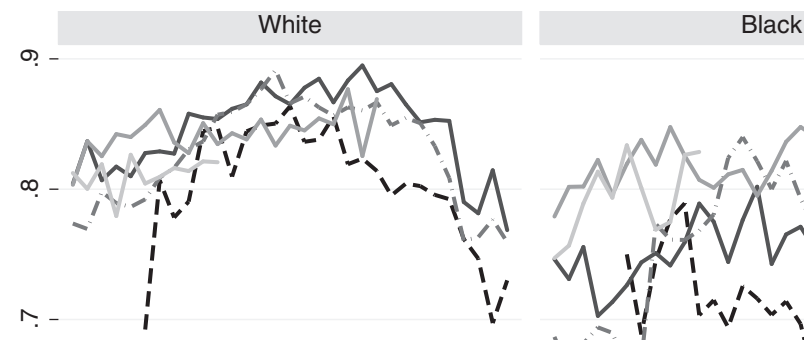

lack

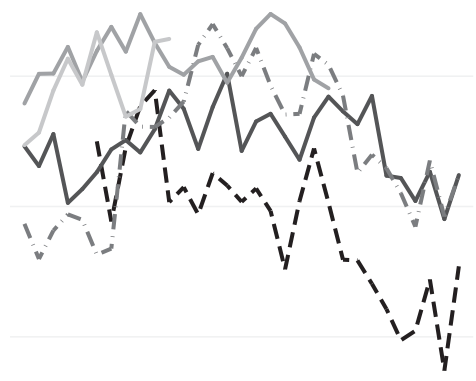

$\varphi$

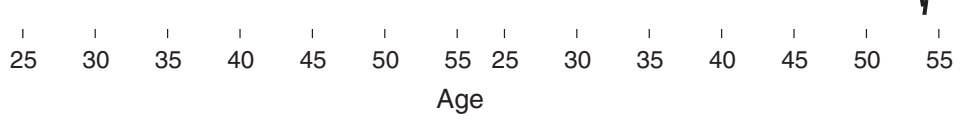

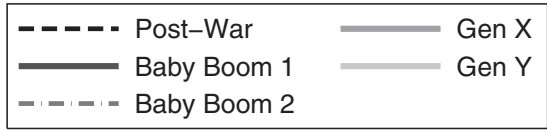

Source: Current population survey annual social and economic supplement 1976-2013.

for younger cohorts as compared to older cohorts (Figure 4a). Among white women, more recent cohorts with a high school diploma or less have decreased their labor force participation compared to Baby Boom 2. 
Figure 4. (a) Labor force participation by race: low education (High School or less). (b) Labor force participation by race: high education (Bachelor's Degree plus)

(a)

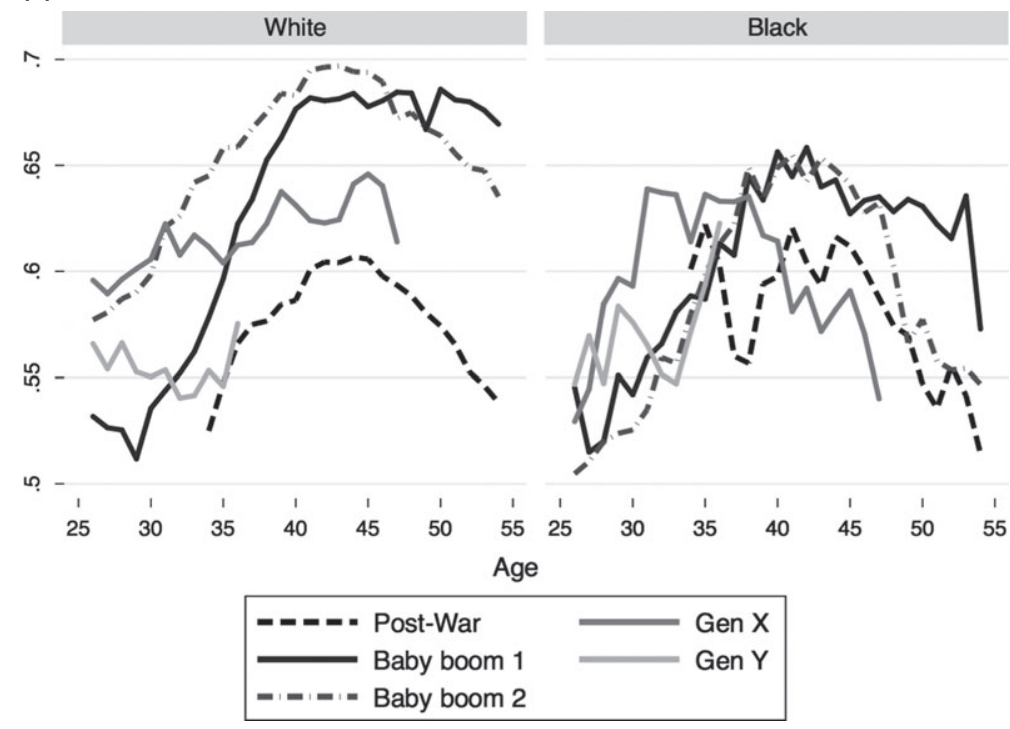

(b)

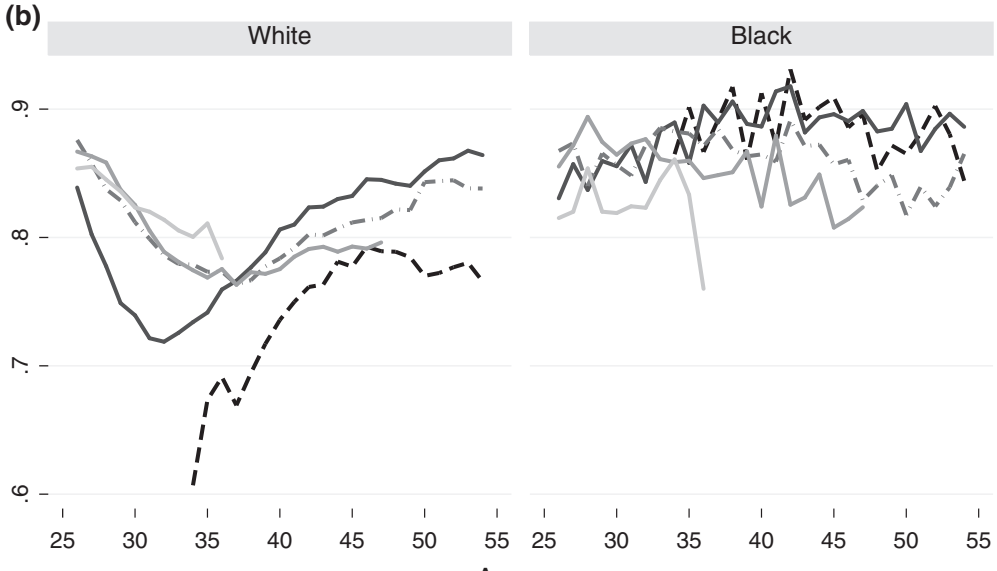
Age

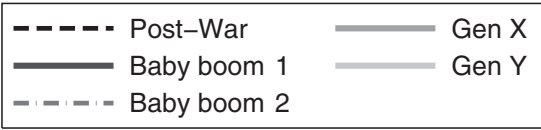

Source: Current population survey merged outgoing rotation groups 1979-2014.

Figure 2a also highlights differences in participation by cohort across childbearing years, between ages 25-35, and after age 35 for white women. Labor force participation among white women is much lower for the Baby Boom 1 cohort than the three subsequent generations during childbearing and early childrearing years. The Baby Boom 1 cohort exhibits a distinct u-shape during these years, with white women appearing to leave the labor force between ages 25-30 and then re-entering at about the same rate between ages $31-35$. The 
later three cohorts also see a decrease in labor force participation between ages 25-30, but the decline and subsequent rise are not nearly as steep, suggesting a change in labor force participation due to advances in contraceptive techniques. After age 35, the cohorts are mostly indistinguishable except that white women in the Baby Boom 1 cohort appear to be more likely to be in the labor force than all other cohorts.

For black women, there appears to be little or no u-shaped pattern between the ages of 25-35 except for Baby Boom 1, and that dip may be more statistical noise than anything else.

Because white women of childbearing age are more likely to leave the labor force than black women (Figure 2a), the labor force participation gap decreases for all cohorts in the late 20 s and early 30 s and then levels out and starts to increase after age 40 (Figure 2b). In their late 20s, white women in the three youngest cohorts are 15-20 per cent more likely to work than black women, whereas the gap is around zero for these three cohorts in the late 30s. After age 40, the labor force participation gap becomes positive for all cohorts and increases through the rest of the prime working years. This u-shape in the labor force participation gap may affect our perception of the observed wage gaps, unadjusted for selection into the labor force. It also supports the need to focus on all ages and not just women in their late 20s and early 30s as was done in Neal (2004) and Albrecht et al. (2015).

Four important facts are documented in these descriptive statistics. First, the increase in labor force participation among younger cohorts is larger for white women than black women. Second, when labor force participation by marital and child status is examined, it appears that the larger contributors to this change are married white women with children and single black women with children entering the labor force. Third, black women on the low end and white women on the high end of the education distribution have increased their labor force participation. Changes in the timing of childbirth and welfare reform may be responsible for these patterns. Lastly, the u-shaped labor force participation pattern that is present only for white women has become less pronounced for younger cohorts. This pattern may be partially explained by easier access to advancements in birth control among white women and delayed childbirth. In the following section, we adjust for selection into employment to determine what role differences in labor force participation between black and white women in younger cohorts may play.

\section{Selection-corrected black and white wage gaps}

Previous research and the patterns above suggest an important role of selection into employment in the observed wage gap (e.g., Neal, 2004). The labor force patterns in Figure $2 \mathrm{a}, \mathrm{b}$ along with the wage gap patterns in Figure $1 \mathrm{a}, \mathrm{b}$ show how selection affects the wage gap, as the median wage gap falls for Baby Boom 1 cohort as white women leave the workforce in their late 20s. Another important finding highlighted above is that the wage gap is larger for younger generations for which there is a larger increase in white labor force participation than black. We formally address this issue by controlling for selection into employment.

Unfortunately, there is no perfect or even agreed upon selection correction technique to appropriately analyse how large a role selection plays in the wage gap. Each method relies on different assumptions about the wage of those not working, which affects the perception of the role of selection. We are primarily interested in whether correcting for selection 
into employment affects our perception of the wage gap across generations. In other words, is the higher observed wage gap in our younger cohorts a result of the changing labor force participation patterns we observed? To examine this question, we use four selection correction techniques and compare the black and white wage gap among women with and without selection correction: imputed wages following Neal (2004), the traditional Heckman selection correction technique, and two methods for predicting wages (Juhn and Murphy, 1997; and Manski, 1995). We now describe those four techniques. ${ }^{6}$

Neal's (2004) technique imputes wages for women with no reported wage using two broad rules. First, wages are imputed by age and cohort for those who have no postsecondary education, received government aid in the previous year, and had no other income (proxying spousal support). This group represents likely welfare recipients with low levels of education who receive no spousal support. Following Neal, an arbitrarily low wage of $\$ 2$ per hour is imputed to these women. Wages are also imputed for a second group of women: those with at least a high school education who received substantial support from their spouse. ${ }^{7}$ An arbitrarily high wage of $\$ 73$ per hour is imputed for these women. Because the Neal imputation wage will only be used in the median regression, the imputed wages are irrelevant as long as they fall on the assumed side of the median. Neal's method works well when using the National Longitudinal of Youth (NLSY) because he is able to use five years of data to assign wages for those not working in the latest year. Using five years of data, Neal has observed or imputed wages for 98 per cent of women. The use of CPS data is limiting, as we do not have the long history of wages. Consequently, 19 per cent of the women in our sample do not have an observed or imputed wage using the Neal method, and the percent varies by cohort from 15 per cent in Generation X to 28 per cent in the Post-War Cohort. Thus the Neal method is imperfect for our purposes because we miss a substantial proportion of non-working women. Because Neal's method relies on variables only available in the ASEC, selection-corrected wage gaps using Neal are only presented using the ASEC.

Next we turn to the other three methods to assign wages for all women. The Manski (1995) technique assigns the 10th percentile wage of a donor cell by age band, education, and cohort for those with no reported wage. ${ }^{8}$ Juhn and Murphy (1997) use the same cell definitions, but assign the cell mean. ${ }^{9}$ We expect more dispersion across donor cells in means than in the 10th percentile and therefore expect that the Juhn and Murphy correction method will have a bigger effect on wage gaps. Lastly, we use a standard Heckmancorrection technique that estimates the likelihood of being in the labor force, using the presence the number of children under the age of 6 in the home to identify the labor force participation decision, following Heckman (1974) and Mulligan and Rubinstein (2008).

For each selection correction method, we run a simple model of log wages on a quartic in potential experience, cohort dummies, race, and race interacted with cohort dummies. Additionally, we present regression results for a fuller model that adds four dummies for education, whether married, metropolitan status, and state fixed effects. We present only the median regressions for both the MORG and ASEC data including part-time workers. ${ }^{10}$ The purpose of presenting varying selection correction techniques is to examine whether the increased wage gap among younger cohorts is an artifice of changing selection into the labor force.

To measure the black-white wage gap, we include dichotomous variables representing each cohort and terms that interact each cohort and a dichotomous variable indicating the woman is white. ${ }^{11}$ The benchmark cohort is Baby Boom 1 as this cohort includes women 
observed for all ages in our sample, ages 25-55. Baby Boom 1 is also the bridge cohort between old labor force patterns and new labor force patterns, as seen in Figure 2a. Using Baby Boom 1 as the omitted category also allows us a direct test of whether the wage gap is higher in the three younger cohorts after correcting for selection. Therefore, the black and white wage gap is calculated by considering the difference in the wage gap between each cohort and Baby Boom 1. Further, measuring the black-white wage gap in this manner allows for the different age distributions in each cohort to be accounted for.

Table 1 shows median regression results using the MORG. The coefficient on white estimates the wage gap between white and black women among Baby Boom 1. The interaction terms of race and cohort indicate how much more or less the wage gap is for the respective cohort relative to Baby Boom 1. The first two columns show results from the sparse and full models without controlling for selection into the labor force. The following four columns provide results for both the Manski and Juhn and Murphy techniques. For all cohorts except Post-War, the wage gap is smaller when controlling for the full set of covariates, indicating that part of the wage gap is due to demographic differences between white and black women. Our main result of interest, however, is not affected by whether we control for the full set of characteristics. The three younger cohorts exhibit a higher racial wage gap than our two older cohorts, Baby Boom 1 and Post-War.

The same patterns emerge when we use the ASEC. The advantage of the ASEC is that it allows us to use the Neal selection technique and the Heckman selection technique. Table 2 shows the ASEC results correcting for selection using all four methods. Here we do not show the sparse model results, only those with the full specification. Results are similar using the sparse models, with the same pattern of a smaller wage gap for those corrected for selection.

For the ASEC results in Table 2, the wage gap for Baby Boom 1 is not statistically different from zero at the 5 per cent level of significance when using the Heckman selection correction technique. For the other four models, the wage gap is around 3-6 per cent for

Table 1. Coefficients from median wage regression using two selection techniques: MORG

\begin{tabular}{|c|c|c|c|c|c|c|}
\hline & \multicolumn{2}{|c|}{$\begin{array}{c}\text { No selection adjust- } \\
\text { ment }\end{array}$} & \multicolumn{2}{|c|}{ Manski Technique } & \multicolumn{2}{|c|}{$\begin{array}{c}\text { Juhn and Murphy } \\
\text { Technique }\end{array}$} \\
\hline & $\begin{array}{l}\text { Sparse } \\
\text { Model }\end{array}$ & $\begin{array}{l}\text { Full } \\
\text { Model }\end{array}$ & $\begin{array}{l}\text { Sparse } \\
\text { Model }\end{array}$ & $\begin{array}{c}\text { Full } \\
\text { Model }\end{array}$ & $\begin{array}{l}\text { Sparse } \\
\text { Model }\end{array}$ & $\begin{array}{c}\text { Full } \\
\text { Model }\end{array}$ \\
\hline White*Post-War & $\begin{array}{r}-0.017 \\
(0.005)\end{array}$ & $\begin{array}{c}0.005 \\
(0.004)\end{array}$ & $\begin{array}{r}-0.045 \\
(0.004)\end{array}$ & $\begin{array}{c}-0.017 \\
(0.004)\end{array}$ & $\begin{array}{c}0.021 \\
(0.003)\end{array}$ & $\begin{array}{c}0.013 \\
(0.003)\end{array}$ \\
\hline White (Baby Boom 1) & $\begin{array}{c}0.078 \\
(0.003)\end{array}$ & $\begin{array}{c}0.058 \\
(0.003)\end{array}$ & $\begin{array}{c}0.076 \\
(0.002)\end{array}$ & $\begin{array}{c}0.049 \\
(0.003)\end{array}$ & $\begin{array}{c}0.064 \\
(0.002)\end{array}$ & $\begin{array}{c}0.064 \\
(0.002)\end{array}$ \\
\hline White*Baby Boom 2 & $\begin{array}{c}0.049 \\
(0.004)\end{array}$ & $\begin{array}{c}0.057 \\
(0.003)\end{array}$ & $\begin{array}{c}0.081 \\
(0.003)\end{array}$ & $\begin{array}{c}0.065 \\
(0.004)\end{array}$ & $\begin{array}{c}0.070 \\
(0.002)\end{array}$ & $\begin{array}{c}0.050 \\
(0.002)\end{array}$ \\
\hline White*Generation X & $\begin{array}{l}0.040 \\
(0.005)\end{array}$ & $\begin{array}{c}0.031 \\
(0.004)\end{array}$ & $\begin{array}{c}0.052 \\
(0.004)\end{array}$ & $\begin{array}{c}0.007 \\
(0.004)\end{array}$ & $\begin{array}{c}0.061 \\
(0.003)\end{array}$ & $\begin{array}{c}0.031 \\
(0.002)\end{array}$ \\
\hline White*Generation Y & $\begin{array}{l}0.055 \\
(0.007)\end{array}$ & $\begin{array}{c}0.030 \\
(0.006)\end{array}$ & $\begin{array}{c}0.057 \\
(0.005)\end{array}$ & $\begin{array}{c}0.019 \\
(0.006)\end{array}$ & $\begin{array}{l}0.056 \\
(0.004)\end{array}$ & $\begin{array}{c}0.018 \\
(0.003)\end{array}$ \\
\hline
\end{tabular}

Source: Current population survey, merged outgoing rotation groups, 1979-2014.

Notes: Dependent variable is log wages. The sparse model adds a quartic in potential experience and dummy variables for each cohort. The omitted category is Baby Boom 1. The full model also includes dummies for education, marital status, metropolitan status, and state fixed effects. The sample size is $1,810,879$ for the results not correcting for selection and 2,590,502 for the selection corrected results. 
Table 2. Coefficients from wage regression using four selection techniques: ASEC

\begin{tabular}{lccccc}
\hline & $\begin{array}{c}\text { No selection } \\
\text { adjustment }\end{array}$ & $\begin{array}{c}\text { Manski } \\
\text { Technique }\end{array}$ & $\begin{array}{c}\text { Juhn and } \\
\text { Murphy } \\
\text { Technique }\end{array}$ & $\begin{array}{c}\text { Neal } \\
\text { Technique }\end{array}$ & $\begin{array}{c}\text { Heckman } \\
\text { Technique }\end{array}$ \\
\hline White*Post-War & 0.012 & -0.085 & 0.007 & -0.029 & 0.001 \\
White & $(0.007)$ & $(0.009)$ & $(0.004)$ & $(0.007)$ & $(0.008)$ \\
White*Baby Boom 2 & 0.026 & 0.061 & 0.062 & 0.056 & 0.009 \\
White*Generation X & $(0.005)$ & $(0.005)$ & $(0.002)$ & $(0.004)$ & $(0.005)$ \\
White*Generation Y & 0.082 & 0.092 & 0.056 & 0.062 & 0.103 \\
& $(0.006)$ & $(0.007)$ & $(0.003)$ & $(0.006)$ & $(0.006)$ \\
& 0.075 & 0.038 & 0.038 & 0.018 & 0.099 \\
& $(0.007)$ & $(0.008)$ & $(0.004)$ & $(0.006)$ & $(0.007)$ \\
SOurce & 0.094 & 0.091 & 0.043 & 0.072 & 0.119 \\
& $(0.009)$ & $(0.010)$ & $(0.005)$ & $(0.008)$ & $(0.009)$ \\
\hline
\end{tabular}

Source: Current population survey, annual social and economic supplement, 1976-2013.

Notes: Dependent variable is log wages. The omitted cohort category is Baby Boom 1 . The model includes a quartic in potential experience, dummy variables for each cohort, dummies for education, marital status, metropolitan status, and state fixed effects. The sample size is 803,345 for the results not correcting for selection and 1,054,367 for the selection corrected results.

Baby Boom 1. As with the MORG results, the wage gap is higher for our three younger cohorts.

Taken together, the results from Tables 1 and 2 tell a compelling story. The wage gap is higher for our three younger cohorts, compared to Baby Boom 1 and the Post-War cohort. These results hold if we do not control for selection into employment, and also when we use four different methods for correcting for selection into employment. ${ }^{12}$ These results expand beyond the work of Albrecht et al. (2015) by studying additional cohorts and by examining all ages, not only a window around age 30 .

\section{Discussion}

The wage gap is higher for younger cohorts despite controlling for observable differences between white and black women and despite controlling for selection into employment. Our work does not attempt to explain the causes of the increasing wage gap. Nevertheless, this section will discuss potential mechanisms that could lead to an increasing racial wage gap among women as well as a discussion of the relationship between our analysis of labor force participation and wages over time.

In the introductory section, we listed several trends that should differentially affect the labor force participation decisions of white and black women among younger cohorts: changing marriage markets and marital patterns; changes in spousal income; changes in the nature and generosity of the social safety net; increased access to birth control; and, changing social norms and attitudes toward women in the labor force. We conjecture that these factors have increased labor supply of white women with relatively high potential wages, and the labor supply of black women with a relatively low potential wages.

A considerable amount of research works to explain the changing labor force participation patterns. For example, changes in the social safety net are expected to increase labor 
force participation among low wage women. Grogger (2003) utilizes the 1978-99 CPS March supplements to examine the effect of time limits imposed with TANF on the labor supply of women, finding an increase of labor supply of 7 per cent. Other work finds the EITC had important and substantial effects on the labor supply of women (Eissa and Liebman, 1996; Meyer and Rosenbaum, 2001; and Nichols and Rothstein, 2015). These changes should have affected black women more than white women. As discussed in Section 4, the labor force participation rate among single black women with children increased. Figure $4 \mathrm{a}$ shows a larger percentage of low-educated black women under the age of 35 in the labor force in younger cohorts, where the same is not true among low-educated white women.

Conversely, increased access to birth control and changing social norms are expected to increase labor force participation among high wage women, especially those married to a high wage earner, which is more likely among white women. We also observed this pattern in Section 4; the u-shaped labor force participation pattern among white women has become less defined for younger cohorts. Recall that Figure 1b shows the observed median wage gap by cohort and age. For all four cohorts where we observe the women at age 25, the wage gap is about 13-14 per cent. After age 25, however, the wage gap for the Baby Boom 1 generation diverges from the three younger cohorts. The wage gap for Baby Boom 1 falls until age 33 with a wage gap just under 5 per cent, whereas the wage gap for the three younger cohorts stays around 15 per cent until age 33. After age 33, the wage gaps begin to converge toward 10 per cent. By age 45, the wage gap is around 10 per cent for all cohorts observed at that age. These patterns are consistent with the (limited) research in this area. Bailey (2006) examines the effect of the introduction of the first birth-control pill, Enovid, in 1960 on the labor supply of women. The analysis studies women born between 1935-60 (partial Post-War, Baby Boom 1, and partial Baby Boom 2) in the CPS March supplements, providing evidence that early legal access to birth control resulted in a 7 per cent increase in labor force participation among women. Baby Boom 1 was the first generation to most likely utilize this drug. Our findings agree with Baily given that later generations should be more likely to utilize measures of birth control as their use became more socially acceptable.

The age-gap pattern seen in Figure $1 \mathrm{~b}$ echoes what was seen in the labor force participation gaps. Recall that the Baby Boom 1 cohort saw a decrease in the labor force participation gap between ages 25-30 and an increase in the labor force participation gap after age 30. The corresponding median wage gap fell, presumably as higher skilled white women left the labor force. Interestingly, Figure $1 \mathrm{~b}$ shows a decrease in the wage gap for the Baby Boom 1 cohort between ages 25-30, but no immediate increase in the median wage gap around age 30 . There was no corresponding increase in the wage gap as more white women re-entered the labor market after age 30, which suggests that returning white women who previously left the labor force to raise children received lower wages than they would have had they stayed in the labor force. Mincer and Ofek (1982) examine the wage penalty associated with interrupted work careers for adult women between 1966 and 1974, finding a significant penalty for each year out of the labor market, consistent with what we observe in Figure $1 b$.

More recent cohorts did not experience the same trend in wage gaps because they did not experience the same exodus of white women out of the labor force as Baby Boom 1 did. Figure $1 \mathrm{~b}$ shows that the median wage gap for women in their late 20 s and early $30 \mathrm{~s}$ did not decrease for Baby Boom 2, Generation X, and Y, as it did for the Baby Boom 1 cohort. The declining exodus from the labor market for white women with children 
appears to be driven by highly educated women. Figure $4 \mathrm{~b}$ shows the labor force participation patterns among those with a college degree or more. There are more highly educated white women in younger cohorts in the labor force, suggesting that more recent cohorts are delaying childbirth to have careers.

Together these patterns suggest a higher wage gap among the younger cohorts that were more affected by these changing patterns. If the changes in labor force participation were the driving force behind the increase in the wage gap, then correcting for selection into employment should diminish the differences across the cohorts. However, the wage gap remains higher among the three younger cohorts even after controlling for selection into employment. Table 3 shows that regardless of the selection correction technique, the wage gap between black and white women has risen for younger cohorts.

If there are no longer drastic differences in selection into employment between black and white women, the difference in the observed wage gap and the selection corrected wage gap for younger cohorts should diminish. The first four columns of Table 3 show the wage gap and selection corrected wage gaps for the ASEC data by cohort. We do find much smaller differences between observed and potential wages for younger cohorts than older cohorts.

Mechanically, the wage gap rose because median wages for white women rose for the three younger cohorts but median wages for black women fell for the three younger cohorts (see Figure 1a) before age 35. Median wages for black women younger than 35 in Baby Boom 1 are higher than wages for Baby Boom 2, Generation X, and Generation Y. After age 35, the three younger cohorts have higher wages than the Baby Boom 1, but they still have not caught up with white women. We posit an explanation for these results for future research here.

Although there has been a focus on the gender wage gap and some progress has been made in narrowing the gender wage gap, the closing of the gender wage gap may have disproportionately affected white women. This story is consistent with what we see in Figure 1a, where the wages of white women increase for younger cohorts although we observe a decrease in median wages for black women. There is a larger share of women in higher paid and more prestigious occupations in younger cohorts as compared to older, however, these positions are largely filled by white women (Smith, 2002 and Wilson, 2012). Occupational segregation, discrimination, and changes in the percentage of white women in these

Table 3. Observed versus potential wage gaps

ASEC

\begin{tabular}{lccccc}
\cline { 3 - 5 } & & \multicolumn{4}{c}{ Potential wage gap } \\
\cline { 3 - 5 } $\begin{array}{c}\text { Observed wage gap } \\
\text { No selection }\end{array}$ & Manski & Juhn \& Murphy & Neal & Heckman \\
\hline Post-War & 0.038 & -0.024 & 0.069 & 0.027 & 0.010 \\
Baby Boom 1 & 0.026 & 0.061 & 0.062 & 0.056 & 0.009 \\
Baby Boom 2 & 0.108 & 0.153 & 0.118 & 0.118 & 0.112 \\
Generation X & 0.101 & 0.099 & 0.100 & 0.074 & 0.108 \\
Generation Y & 0.120 & 0.152 & 0.105 & 0.128 & 0.128 \\
\hline
\end{tabular}

Source: Current population survey, annual social and economic supplement, 1976-2013.

Notes: Results are based off median regression results from Table 2. 
higher paid occupations may help to explain the rising wage gap among black and white women.

Although an evaluation of the role of occupational segregation is outside the scope of this paper, we provide some descriptive analysis to highlight patterns. We chose to focus on one high-wage occupation category, Professional/Managerial and one low-wage occupation category, Healthcare Support. We focus on women aged 25-35 and therefore exclude the Post-War cohort as we would only be including women aged 34-35. Table 4 shows the percentage of women employed in each profession by race and cohort. We find that the percent of women within professional managerial occupations increased over time by cohort for both black and white women. White women in any cohort are 3-7 percentage points more likely to be in professional managerial occupations, with no real pattern of change by cohort. Thus we do not see support for the hypothesis that white women are gaining entry into these occupations faster than black women. We do, however, find that the median wage gap among those in the professional/managerial occupations is higher for younger cohorts.

Table 4 also shows that employment in healthcare support occupations has increased for younger cohorts of black and white women, where the change is much larger for black women. In other words, over time, more black women are entering into healthcare support occupations than white women. Additionally, white women continue to be paid more at

Table 4. Labor force participation and wages by occupation for those ages 25-35

\begin{tabular}{|c|c|c|c|c|c|c|}
\hline & \multicolumn{6}{|c|}{ Healthcare support } \\
\hline & \multicolumn{4}{|c|}{ All } & \multicolumn{2}{|c|}{ Child Under 6} \\
\hline & \multicolumn{2}{|c|}{$\begin{array}{l}\text { Per cent employed in } \\
\text { healthcare support }\end{array}$} & \multicolumn{2}{|c|}{ Median wages } & \multicolumn{2}{|c|}{ Per cent employed } \\
\hline & White & Black & White & Black & White & Black \\
\hline Baby Boom 1 & 0.04 & 0.07 & 14.13 & 12.15 & 0.80 & 0.98 \\
\hline Baby Boom 2 & 0.03 & 0.03 & 16.91 & 15.10 & 0.82 & 0.87 \\
\hline Generation X & 0.05 & 0.10 & 14.65 & 12.48 & 0.92 & 0.87 \\
\hline \multirow[t]{5}{*}{ Generation Y } & 0.07 & 0.14 & 13.41 & 11.73 & 0.90 & 0.85 \\
\hline & \multicolumn{6}{|c|}{ Professional/Managerial } \\
\hline & \multicolumn{4}{|c|}{ All } & \multicolumn{2}{|c|}{ Child Under 6} \\
\hline & \multicolumn{2}{|c|}{$\begin{array}{c}\text { Per cent in employed } \\
\text { in Professional/ } \\
\text { Managerial }\end{array}$} & \multicolumn{2}{|c|}{ Median wages } & \multicolumn{2}{|c|}{ Per cent employed } \\
\hline & White & Black & White & Black & White & Black \\
\hline Baby Boom 1 & 0.12 & 0.07 & 19.41 & 20.21 & 0.75 & 0.89 \\
\hline Baby Boom 2 & 0.17 & 0.10 & 20.23 & 18.68 & 0.75 & 0.86 \\
\hline Generation X & 0.19 & 0.14 & 20.53 & 19.27 & 0.93 & 0.93 \\
\hline Generation Y & 0.15 & 0.12 & 20.51 & 18.82 & 0.93 & 0.89 \\
\hline
\end{tabular}

Source: Current population survey, merged outgoing rotation groups, 1979-2014. 
the median, and the wage gap is increasing across cohorts. The wage gap among women in healthcare support occupations ranges from 11 per cent for the Baby Boom 2 cohort to 15 per cent in Generation X.

Additionally, we see the declining role of selection into the labor force for white women in both occupations. The CPS asks for occupation even if the respondent is not working, which allows us to know of the previous occupation for women who left the labor market to care for young children. The last two columns of Table 4 shows the percent of women with at least one child under the age of 6 in the home employed in a given occupation. Of the women in Baby Boom 1 with a child under the age of 6 in the home who reported being in a professional/managerial occupation, only 75 per cent were currently employed, whereas 89 per cent of similar black women were currently employed. This suggests that the high wage white women were more likely to leave the labor force to care for young children in Baby Boom 1. That result disappears for Generation X and Generation Y, with the same or a higher percentage of white women remaining employed even with young children in the home. ${ }^{13}$ Future research can look into occupational sorting among women by race to address this potential explanation.

\section{Conclusion}

The increasing wage gap can be contextualized through an understanding of the related economic and social forces. Changing social attitudes led more highly educated white women to enter and remain in the labor force. Federal and state welfare reform led more low educated black women to enter the labor force as time limits and a decrease in the generosity of benefits led more women to seek employment. For instance, we find a proportionally larger increase in the labor force participation of young single black women with children and low educated young black women for more recent cohorts as compared to white women.

Further, the labor force participation decisions of earlier cohorts, like Baby Boom 2, are more likely to be affected by changes in social attitudes, access to birth control, and changes in male earnings. Women from Generation $\mathrm{X}$ and Generation $\mathrm{Y}$ will also alter their labor force participation as birth control continues to advance in quality and quantity and social attitudes soften towards women working, as well as in response to changes in male earnings. We find that the u-shaped pattern only present for white women has become flatter for younger generations, indicating that white women appear to be delaying childbirth for careers. This change among potential high wage white earners is partially responsible for an increase in the black and white wage gap. We also find that among married women with children, later cohorts saw disproportionate increases in labor force participation among white women, whereas the opposite is true for single women with children. Further, we also find an increase in the labor force participation of highly educated white women in more recent cohorts during childbearing years. If middle class white women are entering the labor force to provide additional income to their families, the wage gap between white and black women should increase.

We find a persistent and increasing female racial wage gap for younger cohorts, where white women continue to earn more than black women. If positive selection into employment for black women and/or negative selection into employment for white women is more prevalent among the older cohorts, then we would expect to see an increase in the wage 
gap for more recent cohorts. This explanation would confirm the basic finding of Neal (2004) that selection plays an important issue for the racial wage gap for women. We present evidence for a decrease in the role of selection into employment for both white and black women. However, the declining role of selection does not help to explain the increase in the wage gap between black and white women.

We contribute to the literature in several ways. First, by analysing five cohorts and focusing on a wide age range we highlight the important differences in labor force participation rates by age and cohort, as well as race. Our deeper inspection allows us to highlight these important differences. Adding older and younger cohorts highlights the large differences between Baby Boom 1 and the three younger cohorts, and not between Baby Boom 2 and Generation Y as shown in Albrecht et al. (2015). Further, testing the sensitivity of our results to the different selection correction methods gives us more confidence in the results.

This paper does not aim to identify the causal factors that led to the observed increase in the female racial wage gap. Rather, this research serves as a starting point for much needed subsequent research. The role that occupational segregation plays is an important area for future research. The black and white wage gap is also likely to have increased due to an increase of white women in higher paid and more prestigious occupations than previous generations and an increase in occupational segregation among black and white women.

\section{Notes}

${ }^{1}$ Chetty et al. (2016) examine employment rates for men and women in Generation Y and unsurprisingly find that there are more men employed than women. However, the result flips when considering parental income. Women with low-income parents in Generation Y have a higher employment rate than men with low-income parents. Although Chetty et al. (2016) does not have race, their results also help explain why more black women are employed than black men.

${ }^{2}$ We performed the following analysis including and excluding part-time workers. The results were identical. Therefore, we include wages for both part and full-time workers. Restricting to full-time year round would potentially introduce bias if one group is more likely to work part-time than the other and their wages are relatively low. However, including part-time wages may also bias the wage gap if one group has lower part-time wages due to lower levels of experience and a higher percentage of part-time workers. We believe the information contained in the part time wage is being more valuable than the potential bias introduced by including part time wages.

${ }^{3}$ Because we focus on the median wage gap instead of the mean gap, top-coded earnings will not affect our results.

${ }^{4}$ The median wage gap is similar for the 25 th percentile of the wage distribution, as well as the 75 th percentile (results not shown here, available upon request). The findings do not change significantly and are consequently not shown here. Additionally, the analysis was performed excluding any imputed wage or salary data. There were no significant changes with these exclusions as well, and those results are not shown.

${ }^{5}$ Figure $3 \mathrm{a}, \mathrm{b}$ use the CPS-ASEC because the variable identifying whether any children are present is missing in the MORG from 1979 to 1983 and from 1994 to 1998.

${ }^{6}$ Blundell et al. (2007) provide another selection correction method incorporating Manski bounds, but we are unable to implement this method with our sample of women. The Blundell et al. (2007) correction method relies on the assumption of positive selection into the labor force, and Neal (2004) shows that the assumption fails for white women in the United States.

${ }^{7}$ To follow Neal (2004), this was assumed to be incomes above $\$ 45,000$. 
${ }^{8}$ We modify the Manski approach slightly. Manski used the minimum observed wage whereas we use the observed wage at the 10th percentile of the donor group.

${ }^{9}$ We use 5-year age bands (e.g., ages 31-35). We create six education categories: less than high school; terminal high school diploma or GED; some college with no degree; some college with an associate's or equivalent degree; terminal bachelor's degree or graduate education with no degree; and, graduate education with a degree.

${ }^{10}$ OLS results and results excluding part-time workers are available upon request. The results are unchanged when using OLS or excluding part-time workers.

${ }^{11}$ In results not shown here, we also measure the black-white wage gap with separate wage equations by cohort and find that the wage gap is very similar for each estimation method, although Generation $\mathrm{Y}$ has a smaller wage gap when estimated with pooled cohorts. The smaller wage gap in the pooled regression is expected because Generation $\mathrm{Y}$ only includes relatively young women when observed wage gaps are the largest (Figure 1b). Once controlling for the different age distributions among cohorts in the pooled regression, we account for the differing age distribution.

${ }^{12}$ As noted above, the result also holds when we exclude part-time workers and when we run separate regressions by cohort instead of a pooled regression.

${ }^{13}$ We observe the same patterns for two other highly educated occupations - teachers and healthcare practitioners.

\section{References}

Albrecht J., van Vuuren A. and Vroman S. (2015) 'The Black-white Wage Gap Among Young Women in 1990 cs. 2011: The Role of Selection and Educational Attainment', Labour Economics 33: 66-71.

Bailey M. J. (2006) 'More Power to the Pill: The Impact of Contraceptive Freedom on Women's Life Cycle Labor Supply', The Quarterly Journal of Economics 121(1): 289-320.

Besharov D. J. and West A. (2002) “African American Marriage Patterns', Beyond the Color Line : New Perspectives on Race and Ethnicity in America" in Thernstrom A. and Thernstrom S. (eds.) New York: Hoover Institution Press Publication: 95-113.

Blank R. M. (2002) 'Evaluating Welfare Reform in the United States', Journal of Economic Literature 40(4): 1105-1166.

Blau F. and Kahn L. (2007) 'Changes in the Labor Supply Behavior of Married Women: 1980-2000', Journal of Labor Economics 25(3): 393-438.

Blundell R., Gosling A., Ichimura H. and Meghir C. (2007) 'Changes in the Distribution of Male and Female Wages Accounting for Employment Composition Using Bounds', Econometrica 75(2): 323-363.

Bonczar T. P. (2003) 'Prevalence of Imprisonment in the U.S. Population, 1974-2001', Washington: U.S. Dept. of Justice, Office of Justice Programs, Bureau of Justice Statistics. August, 2003. Web. <https://www.bjs.gov/content/pub/pdf/piusp01.pdf>

Chetty R., Hendren N., Lin F., Majerovitz J. and Scuderi B. (2016) 'Childhood Environment and Gender Gaps in Adulthood', NBER Working Paper No. 21936.

Eissa N. and Liebman J. (1996) 'Labor Supply Response to the Earned Income Tax Credit', Quarterly Journal of Economics 111(2): 605-637.

Fisher J. D. and Houseworth C. A. (2012) 'The Reverse Wage Gap among Educated White and Black Women', Journal of Economic Inequality 10(4): 449-470.

Goldin C., Katz L. and Kuziemko I. (2006) 'The Homecoming of American College Women: The Reversal of the College Gender Gap', Journal of Economic Perspectives 20(4): 133-156.

Greenwood J., Guner N., Kocharkov G. and Santos C. (2014) 'Marrying Your Like: Assortative Mating and Income Inequality', NBER Working Paper No. 19829. 
Grogger J. (2003) 'The Effects of Time Limits, the EITC, and Other Policy Changes on Welfare Use, Work, and Income among Female-headed Families', Review of Economics and Statistics 85(2): 394-408.

Heckman J. (1974) 'Shadow Prices, Market Wages, and Labor Supply', Econometrica 42(4): 679-694.

Hirsch B. T. and Winters J. V. (2014) 'An Anatomy of Racial and Ethnic Trends in Male Earnings in The U.S.', Review of Income and Wealth 60(4): 930-947.

Juhn C. and Murphy K. (1997) 'Wage Inequality and Female Labor Supply', Journal of Labor Economics 15(1): 72-97.

Juhn C. and Potter S. (2006) 'Changes in Labor Force Participation in the United States', Journal of Economic Perspectives 20(3): 27-46.

Klerman J. and Leibowitz A. (1995) 'Explaining Changes in Married Mothers', Employment over Time', Demography 32(3): 365-378.

Manski C. F. (1995) Identification Problems in the Social Sciences. Cambridge, MA: Harvard University Press.

McHenry P. and McInerney M. (2014) 'The Importance of Living an Education in Estimates of the Conditional Wage Gap Between Black and White Women', The Journal of Human Resources 49(3): 695-722.

Meyer B. and Rosenbaum D. (2001) 'Welfare, the Earned Income Tax Credit, and the Labor Supply of Single Mothers', Quarterly Journal of Economics 116(3): 1063-1114.

Mincer J. and Ofek H. (1982) 'Interrupted Work Careers: Depreciation and Restoration of Human Capital', Journal of Human Resources 17(1): 3-24.

Mishel L., Bivens J., Gould E. and Shierholz H. (2012) The State of Working America, 12th edn. Ithaca: ILR Press.

Mulligan C. and Rubinstein Y. (2008) 'Selection, Investment, and Women's Relative Wages Over Time', Quarterly Journal of Economics 123(3): 1061-1110.

Neal D. (2004) 'The Measured Black-White Wage Gap among Women is Too Small', Journal of Political Economy 112(1): S1-S28.

Nichols A. and Rothstein J. (2015) 'The Earned Income Tax Credit (EITC)', NBER Working Paper No. 21211.

Pew Research Center: Social and Demographic Trends (2009) The Harried Life of the Working Mother. Washington, D.C.: Pew Internet \& American Life Project.

Ruggles S. (2014) 'Marriage, Family Systems, and Economic Opportunity in the United States Since 1850', University of Minnesota Working Paper No. 2014-11.

Shank S. E. (1988) 'Women and the Labor Market: The Link Grows Stronger', Monthly Labor Review 111(3): 3-8.

Smith R. (2002) 'Race, Gender, Authority in the Workplace', Annual Review of Sociology 28: 509542.

Wilson G. (2012) 'Women's Mobility into Upper-Tier Occupations: Do Determinants and Timing Differ by Race?', The Annals of the American Academy of Political and Social Science 639: $131-148$. 